\title{
Enfekte veya kemik defektli kaynamamalarda kullanılan özel teknikler: indükte membran - Masquelet tekniği
}

\author{
Techniques for use with infected or bone defects: \\ induced membrane - Masquelet technique
}

\author{
Mahmut Kalem¹, Mustafa Kavak \\ ${ }^{1}$ Ankara Üniversitesi Tıp Fakültesi, Ortopedi ve Travmatoloji Anabilim Dalı, Ankara \\ ${ }^{2} \mathrm{Op}$. Dr. Ergun Özdemir Görele Devlet Hastanesi, Giresun
}

\begin{abstract}
Geniş diafizer kemik defeklerinin rekonstrüksiyonu, kemik kaybının etiyolojisi ne olursa olsun ekstremite kurtarmada en büyük sorundur. Bu sorunun çözümünde günümüzde kabul görmüş, en bilinen ve yaygın olarak kullanılan prosedürler; vaskülarize kemik transferi, Ilizarov-distraksiyon tekniği ile osteogenezis ve indükte membran (IM) tekniğidir. Masquelet ve ark. 1986'da geliştirdikleri bu teknik, kemik defektlerinin rekonstrüksiyonunda kabul görmüş, basit ve etkili bir yöntemdir. Masquelet ve ark. bu tekniği başlangıçta sadece enfekte kaynamamaya bağı kemik kaybı için tanımlamışlar, fakat zaman içerisinde bu yöntem, nedeni ne olursa olsun, birçok kemik defekti rekonstrüksiyonunda da kullanılmaya başlanmıştır. Teknik olarak çok karmaşık olmayan ve yüksek cerrahi beceri gerektirmeyen bu yöntemin başarısı için, prensiplere kesinlikle uyulmalıdır. Literatüre bakıldığında septik kaynamama tedavisinde IM-Masquelet tekniğinin güvenilir bir yöntem olduğu görülmekle birlikte, değişken komplikasyon ve kaynama süreleri bildirilmiştir. Şüphesiz, bu durum septik kaynamama olgularının geniş yelpazede yer alıyor olmasından kaynaklanabilir olsa da, cerrahi teknik detaylar da göz önünde bulundurmalıdır. Mevcut kanıtlara rağmen, klinik gidişi iyileştirmek ve IM tekniğinin kullanımı ile ilgili konuları netleştirmek için daha ileri araştırmalara gerek vardır.
\end{abstract}

Anahtar sözcülkler: Masquelet tekniği; indükte membran tekniği; defektif kaynamama; kemik defekti; kemik rekonstrüksiyonu
Reconstruction of large diaphyseal bone defects is the biggest problem in the recovery of the extremity regardless of the etiology of bone loss. The most well-known and widely used procedures currently accepted for solving this problem are vascularized bone transfer, Ilizarovdistraction technique, and induced membrane (IM) technique. This technique, developed by Masquelet et al. in 1986 , is an accepted, simple, and effective method of reconstruction of bone defects. Masquelet et al. initially described this technique only for bone loss due to infection non-union, but over time this method has begun to be used in many bone defect reconstructions for whatever reason. Technically, this method, which is not too complicated and does not require high surgical skills, must be followed strictly for its success. Literature review suggests that IM-Masquelet technique is a reliable method in the treatment of septic non-union, but variable complication and union times are reported. Undoubtedly, this may be due to the fact that septic non-union cases are located in a wide range, but surgical technique details should also be taken into consideration. Despite the current evidence, further research is needed to clarify the use of the IM technique and to improve the clinical outcomes.

Key words: Masquelet technique; induced membrane technique; defective non-union; bone defect; bone reconstruction

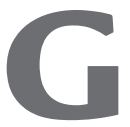
eniş diyafizer kemik defeklerinin rekonstrüksiyonu, kemik kaybının etiyolojisi ne olursa olsun ekstremite kurtarmada en büyük sorundur. Bu sorunun çözümünde günümüzde kabul görmüş, en bilinen ve yaygın olarak kullanılan prosedürler, vaskülarize kemik transferi ve Ilizarovdistraksiyon tekniği ile osteogenezis metodudur. Kemik otogrefti ile rekonstrüksiyon, greft rezorpsiyonu nedeniyle özellikle $6 \mathrm{~cm}$ ve daha büyük diyafiz defektlerinde önerilmez. ${ }^{1,2]}$ Büyük defektlerin rekonstrüksiyonu için önerilen bir diğer metod ise indükte membran (IM) tekniği olarak bilinir ve 30 yılı aşkın süredir kullanılmaktadır. ${ }^{[3]} \mathrm{Bu}$ yöntem yakın geçmişte popülerlik kazanmış ve segmental kemik defektlerinin rekonstrüksiyonu için basit ve etkili bir teknik olarak giderek daha yaygın kullanılmaktadır. Masquelet ve ark. 1986'da kendi geliştirdikleri bu tekniği, başlangıçta sadece enfekte kaynamamaya bağlı kemik kaybı

- İletişim adresi: Uzm. Dr. Mahmut Kalem, Ankara Üniversitesi Tıp Fakültesi, İbni Sina Hastanesi, Ortopedi ve Travmatoloji Anabilim Dalı, Sıhhiye, Ankara Tel: 0312 - 5082282 e-posta: drkalem@hotmail.com

- Geliștarihi: 1 Kasım $2017 \quad$ Kabul tarihi: 1 Kasım 2017 
için tanımlamışlar, zaman içerisinde bu yöntem, nedeni ne olursa olsun, birçok kemik defekti rekonstrüksiyonunda da kullanılmaya başlanmıştır.

Masquelet ve ark. septik kaynamamaları tedavi ederken, ilk aşamada radikal debridman, eksternal fiksatör ve antibiyotik yüklü spacer'lar kullandılar. Başlangıçta kullanılan spacer'ın rolü, yumuşak dokunun kemik defekti içine çökmesini önlemek, kemik rekonstrüksiyonu için yer hazırlamak ve enfeksiyonun eradikasyonu idi. Enfeksiyonun eradikasyonu ve yumuşak doku iyileşmesi sağlanmasını takiben, tedavinin ikinci aşaması sırasında spacer etrafında çok kanayan hipervasküler bir membran geliştiğini fark ettiler ve iyi kanlanan bu membranı eksize etmeden greftleme yaptılar. 1990 yılında, o güne kadar üzerinde çalışmış oldukları olguların şaşırtıcı ve tatminkar sonuçları, onları bu spacer tarafından indüklenen zarın kaynamadaki rolünü aydınlatmak için ileri çalışmalar yapmaya teşvik etti. ${ }^{[4]} \mathrm{Bu}$ amaçla yapılan araştırmaların ilk adımı, zarın rolünü araştırmaktı. Deneysel çaIışma, Davos'un AO Gelişim Enstitüsü'nde yapıldı ve zarın kansellöz kemiğin rezorpsiyonunu önlediği, aynı zamanda otogreftin iyileşmesi üzerinde de olumlu etkisi olduğu hipotezi araştırıldı. Otuz koyun üzerinde yapılan ilk laboratuvar çalışmasında, 3'er cm'lik segmental femur defekti oluşturup, bu defektleri polimetil metakrilat (PMMA) çimento spacer ile doldurdular ve bir plak ile stabilize ettiler. Bir ay sonra spacer çıkarilıp dört grup oluşturuldu:

Grup A: Membran muhafaza edildi ve süngerimsi kemik greftleri ile dolduruldu.

Grup B: Membran eksize edildi ve defekt süngerimsi kemik greftleri ile dolduruldu.

Grup C: Membran tek başına dolum yapılmaksızın muhafaza edildi.

Grup D: Membran eksize edildi ve defekt doldurulmadı.

Beklendiği gibi, C ve D gruplarında herhangi bir kemik oluşumu olmadığını izlediler. B grubunda, kemik iyileşmesi kısmen elde edildi ancak tüm olgularda önemli miktarda greft rezorpsiyonu geliştiğini gördüler. Grup A'da ise başlangıç greft hacmi azalmadan kemik iyileşmesi sağlandı.

Araştırmanın ikinci basamağında, membranın histolojik ve biyokimyasal özelliklerini değerlendirerek kaynamadaki rolünü ortaya koymaya çalıştılar. ${ }^{[3]}$ Bu amaçla yapılan immünohistokimyasal çalışmalar sonucunda;

1. Membranın tüm katmanlarında zengin vaskülarize olduğu,
2. Membranın iç kısmının (spacer'a komşu yüz) sinoviyal epitel ve dış kısmının fibroblastlar, miyofibroblastlar ve kollajenden oluştuğu,

3. Membranın büyüme faktörleri salgıladığı (ikinci hafta başında yüksek miktarda VEGF ve TGF Beta 1, dördüncü haftada ise yüksek miktarda BMP-2) tespit edildi.

Ayrıca membran özütlerinin kemik iliği hücre çoğalmasını ve osteoblastik diferansiyasyonu arttırdığı izlendi.

Masquelet ve ark., 1986-1999 yıları arasında iM tekniği ile tedavi ettikleri septik kaynamama olgularını geriye dönük olarak değerlendirdiklerinde; kaynama oranı ve enfeksiyon eradikasyonunda çok başarılı sonuçlara rağmen kaynama süresinin uzun olduğunu ve sonrasında refraktürler gelişebildiğini gördüler. ${ }^{[5]} \mathrm{Bu}$ durum onları, tedavi süresini kısaltıp sağlamlığı arttıracak farklı çözümler aramaya yönlendirdi. Bu amaçla, otogrefte BMP-7 (Bone Morphogenetic Protein-7) eklediler. Bu sayede, başlarda hızlı densifikasyonu elde etmelerine rağmen sonrasında rezorpsiyon alanlarının geliştiğini gözlemlediler. ${ }^{[3]}$ Ayrıca, başlangıçta konsodile olduğunu gördükleri bazı olgularda, sonrasında ilerleyici deformite geliştiğini gözlemlediler. Sonuçta, bu teknikle beraber büyüme faktörü kullanımının etkilerinin beklenmedik olduğunu ve ek çalışmalara ihtiyaç olduğunu bildirdiler.

\section{TEKNIĞiN ILKELERi (Tablo 1)}

Teknik ilkeler basittir ve yüksek cerrahi beceri gerektirmez. Bununla birlikte, tekniğin başarısı için prensiplere kesinlikle uyulmalıdır. ${ }^{[6]}$

Kemik defekti rekonstrüksiyonu iki aşamadan oluşur. Birinci aşama radikal bir debridman, ortaya çıkan nihai kemik defektinin bir PMMA çimento spacer ile doldurulması, yumuşak doku örtümünün tam olarak (gerekli ise doku flepleri ile) yapılması ve tespitten oluşur. İkinci aşama ise, yumuşak dokunun kesin iyileşmesi elde edildiğinde, ortalama 6-8 hafta sonra yapılır. Bu konuda tek geçerli kural, enfeksiyonun yenilmesi ve yumuşak dokuların mükemmel iyileşmesin sağlanmasıdır. ${ }^{[6]}$ Bazı serilerde, tekrarlayan enfeksiyon nedeniyle kemik rekonstrüksiyonu başarısızlıklarını rapor edilmiş ve bu IM tekniğinin başarısızlığı olarak gösterilmiştir. ${ }^{[7]}$ Ancak unutulmamalıdır ki iM tekniği, enfeksiyon tamamen ortadan kaldırıldığında etkin bir yöntemdir. ${ }^{[6]}$ Bazen, enfeksiyonun eradikasyonu için tekrarlayan kemik ve yumuşak doku debridmanları gerekir (Şekil 1). Buradaki temel hata, zarın vaskülarizasyonunun enfeksiyonun iyileşmesini sağladığı ve antibiyotik yüklü çimentonun daha az önemli 
Tablo 1. Masquelet tekniğinde püf noktalar ${ }^{[26]}$

\begin{tabular}{ll}
\hline 1. AŞAMA & 2. AŞAMA \\
\hline $\begin{array}{l}\text { Enfeksiyonun tedavisi radikal debridman ve irrigasyondur. Kanlanan } \\
\text { kemik uçları ve yumuşak dokuya kadar debridman yapılmalıdır. (Şekil 1) }\end{array}$ & $\begin{array}{l}\text { Ameliyat sırasında antibiyotik verilmeden önce enfeksiyonun varlığını } \\
\text { Eğer çivi çıkarık için kültür örnekleri alınmalıdır. }\end{array}$ \\
\hline
\end{tabular}

\begin{abstract}
Eksternal fiksatör kullanılacaksa pinlerin yerleşiminde mekanik stabiliteden ödün verilmemeli ancak ikinci aşamada planlan insizyon da göz önünde bulundurulmalıdır (Şekil 2).
\end{abstract} Ekstremitenin uzunluğu, mekanik aksı ve rotasyonu korunmalıdır
(Şekil 2).

\begin{abstract}
Optimum membran indüksiyonu ve yapının daha iyi stabilitesi için, çimento kanalın içine ve kemiğin kenarlarına yerleştirilmeli ve rekonstrüksiyon alanını korumalıdır.
\end{abstract}

Enfekte kaynamama olgularda antibiyotik yüklü çimento kullanılmalıdır.

İyi yumuşak doku örtüsü şarttır ve serbest doku transferi gerekebilir.

Yara kapanması gergin olmamalıdır.

bir debridmana izin verdiğini düşünmektir; oysa enfeksiyonun tedavisi radikal debridmandır. ${ }^{[3]}$

íkinci aşamada, spacer çıkarılırken membran korunmalı ve çevre dokulara zarar verilmemelidir. Çimento bir osteotom ve çekiç ile kırılır. Boşluk hafifçe temizlenir. Kemik uçların medüller boşlukları temizlenmeli ve küretlenmelidir; ancak bunu yaparken çimento tarafından indüklenen membranın korunması önemlidir. Boşluk, iliak kanatlardan elde edilen spongiyöz kemik otogrefti ile doldurulur. Sonrasında membran, yumuşak dokularla beraber greftin üzerinden kapatılmalıdır. Hematom greft rezorpsiyonuna neden olduğundan, negatif basıncı olmayan dren kullanılması gereklidir. Kortikalizasyon ile kemik konsolidasyonu, dört ay içinde ilerleyici olarak gözlenir. Unutulmamalıdır ki bu süre, alt ekstremitenin rekonstrüksiyonu için desteksiz tüm ağırlığın verilmesine izin vermek için yeterli değildir. Cerrahi stabilizasyon ne olursa olsun, ağırlık verme aşamalı olmalıdır ve 6-7 ay içerisinde tamamlanmalıdır. ${ }^{[6]}$
Membran dikkatli bir şekilde hasarlanmadan açılmalıdır.

Çimento ara parçası, kemik kenarlarını kırmadan ve kemik kaybına neden olmadan çıkartılmalıdır.

Intramedüller kanal açılmalı ve debride edilmelidir.

Tüm devitalize dokuların çıkarılması gerekir.

Defektin büyüklüğüne göre yeterli miktarda greft materyali elde edilmelidir. Büyük defektler için otolog kemik greft hacmi allogreft ile zenginleştirilebilir.

Kemik grefti, osteoprogenitör hücreler (kemik iliği aspiratından) veya osteoindüktif büyüme faktörleri (ticari olarak mevcut BMP'ler) ile zenginleştirilebilir.

Membran dikkatlice kapatılmalıdır.

Yeterli mekanik stabilite sağlanmalıdır. Kan dolaşımını asgari derecede bozmak ve plağın altındaki zarın sağlam bir şekilde kapatılmasını sağlamak için plak epiperiostal olarak yerleştirilmelidir.

Yumuşak doku örtüsü yeterli olmalı ve yara kapatılması gerginlik olmadan yapılmalıdır.

\section{Spacer}

Spacer'ın içerdiği antibiyotik türünün indüklemiş membran üzerindeki etkileri henüz bilinmemektedir. ${ }^{[7]}$ En yaygın kullanım şekli silindirik olmakla birlikte, spacer'ı defektin şekline göre farklı şekillerde kullanmak mümkündür. Spacer, katılaşmadan önce şekillendirilmeli, yumuşak dokudan ödün vermeden ve mümkün olduğunca büyük tutulmalıdır. Çimento kemiğin uçlarını 2-3 santimetre sarmalıdır (Şekil 2). Yumuşak dokular, katılaşma evresinde ortaya çıkan ısıdan bir parça eldiven ve yıkama ile korunmalıdır. Klavikula, önkol, proksimal ve distal humerus, el ve ayak gibi daha küçük kemiklerde, çimento ara parçasının ikinci aşamada osteotom ve çekiçle çıkarılması kemiği ve yapılacak stabilizasyonunu zayıflatabileceğinden, buralarda nispeten daha kolay çıkarılabilen el yapımı çimento boncuklarının kullanması önerilir. Çimento boncukları ve silindir şekilli spacer arasında, greft iyileşmesi bakımından fark bulanamamıştır. ${ }^{[6]}$ 


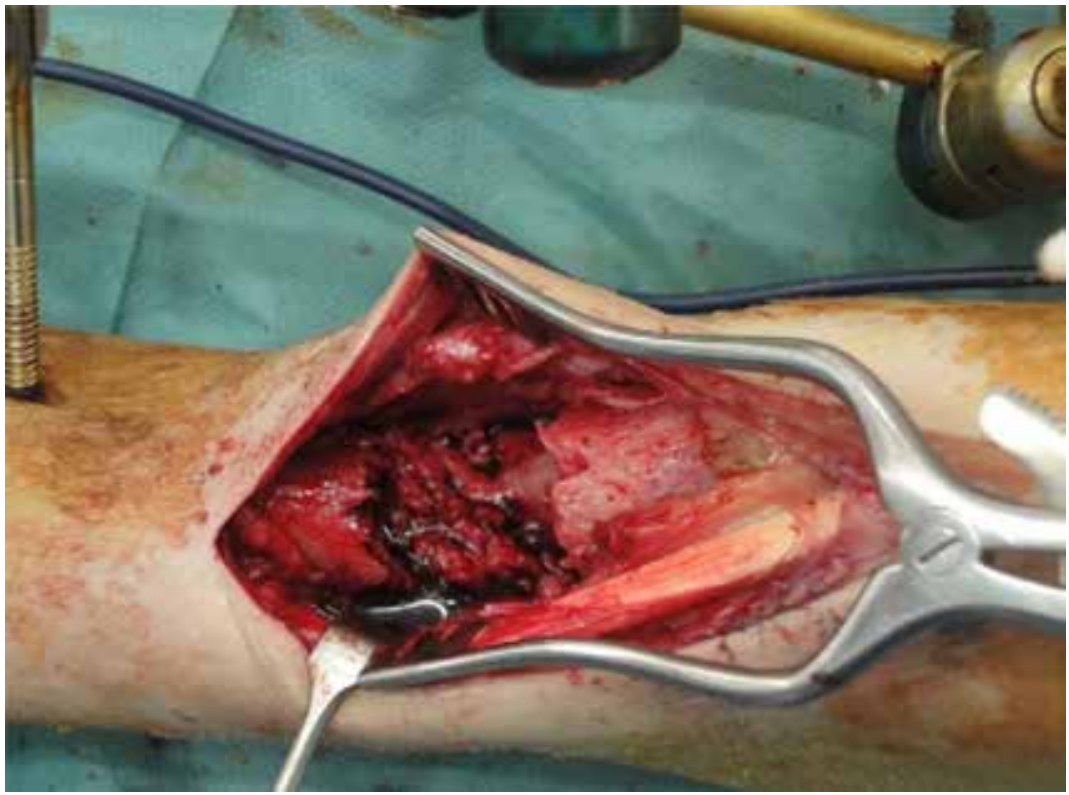

Şekil 1. Kanlanan kemik uçları ve yumuşak dokuya kadar radikal debridman..[26]

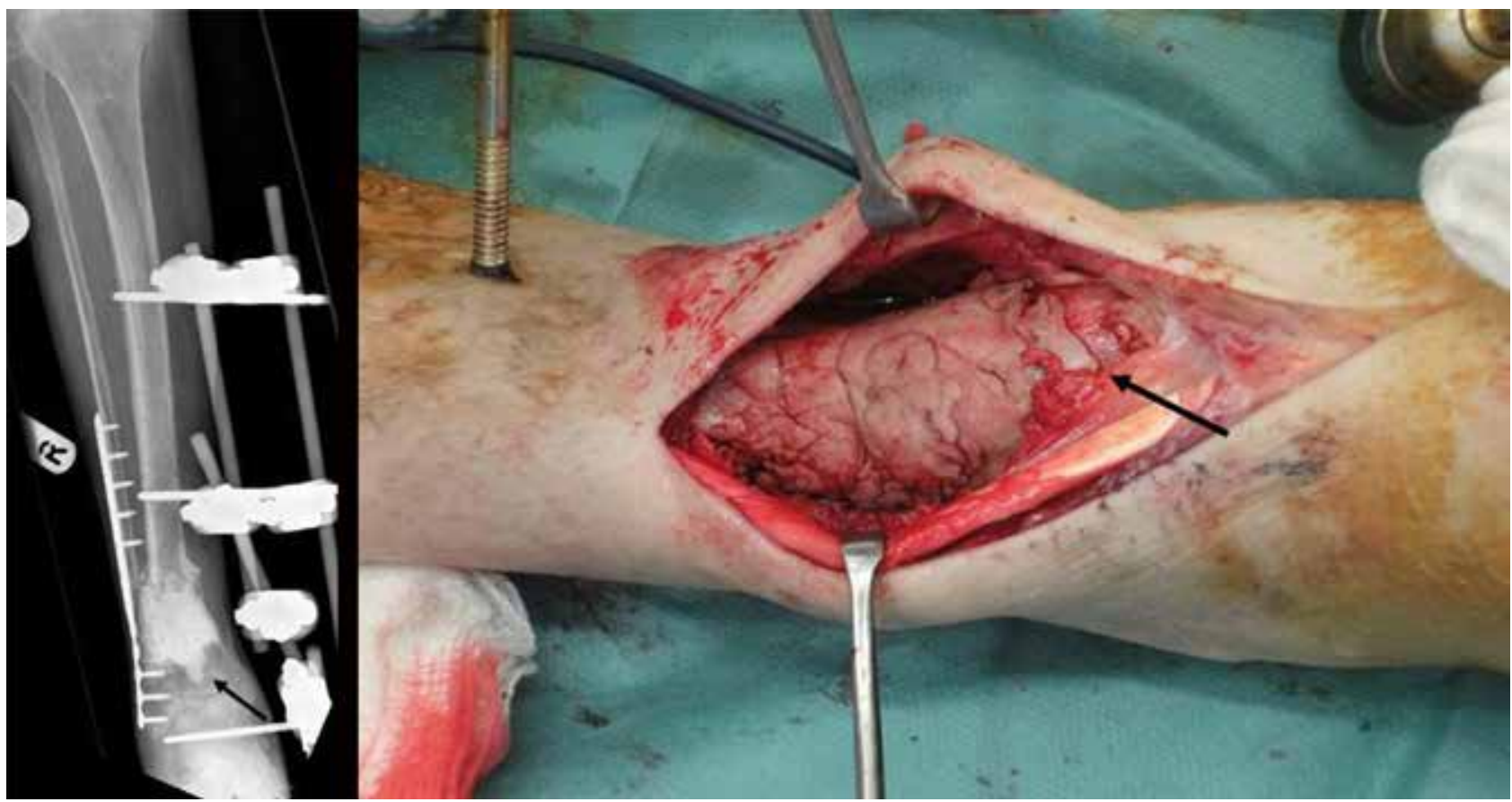

Şekil 2. Optimum membran indüksiyonu ve yapının daha iyi stabilitesi için kanalın içine ve kemi-ğin kenarlarına yerleştirilen çimento spacer. ${ }^{[26]}$

\section{Tespit}

Temel prensip, greft revaskülarizasyonunu sağlamak için ikinci aşamadan hemen sonra mümkün olduğunca rijid, sonrasında ise kortikalizasyonu arttırmak için daha esnek bir tespit yapmaktır. İntramedüller çivi ve eksternal fiksatörler bu iş için oldukça uygundur.
Eksternal fiksatörler, kademeli olarak çıkartılarak aşamalı ağırık taşımaya izin verilebilir. Plaklar, özellikle üst ekstremitede kullanılabilir, ancak muhtemelen greftin kortikalizasyonuna engel teşkil edecek şekilde çok rijid bir stabilite sağlayan kilitli vidaların kullanımı tavsiye edilmez. ${ }^{[6]}$ 


\section{Greft}

Altın standart, iliak krestlerden alınan spongiyöz otogreft kullanımıdır. Büyük ve kortikal kemik otogreftler revaskülarize olamayacağı için uygun değildir. Masquelet ve ark. kendi deneyimlerinde, iliak krestlerden elde edilen kemik grefti ile $15-20 \mathrm{~cm}$ boyutlarında bir tibia diyafiz defektinin rekonstrüksiyonunun mümkün olduğunu ve donör sahada morbidite gelişmediğini söylemişlerdir; ancak farklı çalışmalarda, uzamış ağı, hipertrofik skar, enfeksiyon, duyu bozukluğu gibi donör saha morbiditeleri bildirilmiştir. ${ }^{[8-10]}$ İntramedüller kanal kemik oyma (ICBR) tekniği ile elde edilen otogreft, osteoblastik potansiyeli ve elde edilen canlı kemik hücreleri sayesinde, iliak kanata benzer bir kemik grefti kaynağı olarak kullanılabilir. ${ }^{[11,12]}$ Allogreftler, donör saha morbiditesini arttırmamak için otogreftler ile birlikte kullanılabilse de, kök hücreler ve büyüme faktörleri içermediğinden, allogreft/otogreft oranının 1/3'ü aşmaması önemlidir. Greftler özenle impakte edilerek tüm boşluk doldurulmalı ve herhangi bir çökme olmamasına dikkat edilmelidir. Rekombinant büyüme faktörünü greft ile beraber kullanmanın zararlı olabileceği gözlemlenmiştir. Çünkü, lokalize yüksek yoğunluklu rekominant büyüme faktörü ile salgılanan büyüme faktörlerinin rekabetinin olası etkilerinin, greftin kısmen rezorpsiyonuna neden olabileceği ileri sürülmüştür. ${ }^{[3]}$

\section{Bazı özel durumlar ${ }^{6]}$}

1. Tibia rekonstrüksiyonu için intertibiofibular füzyon dayanıklılığı arttıracaktır.

2. Femurun rekonstrüksiyonunda, varus bükülme kurvetlerine karşı koymak için rekonstrüksiyonun mediyal yüzeyi üzerinde zarın içine yerleştirilen interkalar, nonvaskülarize segmental fibula greftine ihtiyaç vardır. Bu fibula üzerinde, membran tarafindan revakülarizasyonunu ve entegrasyonunu hızlandırmak için küçük çoklu delikler açilır.

Literatüre bakıldığında, septik kaynamama tedavisinde IM-Masquelet tekniğinin enfekte defektif kaynamama tedavisinde güvenilir bir yöntem olduğu görülmekle birlikte, değişken komplikasyon ve kaynama süreleri bildirilmiştir. Şüphesiz bu durum, septik kaynamama olgularının geniş bir yelpazede yer alıyor olmasından kaynaklanabilir olsa da, cerrahi teknik ayrıntılar da göz önünde bulundurmalıdır. Ayrıca, öngörülebilir potansiyel komplikasyonlardan hasta her zaman haberdar edilmelidir. Olguların çoğunda, yeniden yapılandırma süreci uzun ve zor olduğundan, daha fazla cerrahi prosedür gerekebilir.

Toplamda 427 hastanın en az bir yıllık takiplerini içeren bir meta-analizde, iM-Masquelet tekniği ile tedavi sonrası kaynamanın \%89, enfeksiyonun tedavi başarısının ise \%91 olduğu görülmüştür. Kemik defekti boyutlarının 0,6 ile $26 \mathrm{~cm}$ arasında değiştiği bu meta-analizde, reoperasyon oranları ise \%18 olarak bulunmuştur. [13] Wang ve ark. 2016'da yaptıkları geriye dönük çalışmada, alt ekstremitede toplam 32 septik kaynamama olgusunu Masquelet tekniği ile tedavi etmişler, değişen debridman sayılarına rağmen tüm olgularda enfeksiyon eradikasyonu ve kaynamayı sağladıklarını bildirmişlerdir. ${ }^{[14]}$ Ayrıca, çalışmalarında debridmanın kapsamı, ekstremite tespit türü ve kullanılacak kemik grefti kaynağı konusunda karşılaştıkları zorluklardan bahsettiler. IM tekniği ile tedavi edilmiş 84 olguluk farklı bir septik kaynamama serisinde, kaynama oranı $\% 90$, kaynama süresi ise ilk aşama cerrahi sonrası ortalama 14,4 ay olarak bildirilmiştir. ${ }^{15]}$

Ilizarov-distraksiyon osteogenezisi gibi kemik defekti rekonstrüksiyon yöntemi ile karşılaştırıldığında, iM tekniği, iyileşme süresinin defekt uzunluğundan bağımsız olması gibi avantaja sahiptir. IM tekniğinin bir diğer avantajı, kemik defekt rekonstrüksiyonunda kullanılan vaskülarize kemik transferinde olduğu gibi mikro-cerrahi yaklaşım gerektirmemesidir. Bununla birlikte, IM tekniği yaşlı hastalar için distraksiyon osteogenezise kıyasla uygun olmayan ve yüksek riskli iki invaziv cerrahi prosedür gerektirmektedir. Ayrıca, yumuşak doku örtüsü yetersiz ise, iM tekniği ilk adımda yumuşak doku rekonstrüksiyonu gerektirir. Ayrıca, iM tekniği rekonstrüksiyonu, burulma ve bükülme gerilmelerine karşı daha az dirençlidir. ${ }^{[16]}$

\section{Ek büyüme faktörlerinin kullanımı}

Ortotopik hayvan modellerinde, rekombinant insan BMP-7 ve rekombinant insan BMP-2'nin hızlandırıcı kemik iyileştirilmesinde etkili olduğu kanıtlanmıştır. ${ }^{[17]}$ BMP'nin hedefi, konakçı kemik yatağındaki perivasküler bağ dokusu hücreleridir. ${ }^{[18]}$ Klinik çalışmalar, insan morfojenik proteini ile zenginleştirilen süngerimsi kemik greftinin, tibianın segmental defektlerini onarma ve yeni kemik gelişimini arttırma olasılığını göstermiştir. ${ }^{[19-21]}$ Randomize ileriye dönük bir çalışmada, tibia kırık kaynamasında BMP-7'nin iliak kanat otogrefti ile eşdeğer etkinlikte olduğu ileri sürülmüştür. ${ }^{[22]} \mathrm{Bir}$ diğer ileriye dönük, randomize, kontrollü çalışmada ise açık tibial kırıkların tedavisinde BMP-2'nin kemik iyileşmesini hızlandırdığı ve ikincil müdahalelere olan ihtiyacı azaltmada etkili olduğu gösterilmiştir. ${ }^{[23]} \mathrm{Bu}$ nedenle, Masquelet ve ark. 2000 yılı başında kullandıkları otogrefte BMP-7 eklediler. ${ }^{[3]}$ Başlardaki hızlı densifikasyona rağmen, sonrasında rezorpsiyon alanlarının geliştiğini gözlemlediler. Ayrıca, konsolide olduğunu gördükleri bazı olgularda, sonrasında ilerleyici 
deformite gözlemlediler. Bunun nedenini ise; lokalize yüksek yoğunluklu rekominant büyüme faktörü ile salgılanan büyüme faktörlerinin rekabetinin olası etkilerinin greftin kısmen rezorpsiyonuna yol açması olarak düşündüler. Ayrıca, BMP-7'nin insan kemik hücrelerinin çoğalmasını ve in vitro olarak farklılaşmasını stimüle ettiği bilinse bile, BMP-7'nin yüksek dozunun, vitamin $D$ varlığında ALP (alkalin fosfataz) aktivitesini inhibe etmesinin bu sonuca neden olabileceğini belirttiler. ${ }^{[24]}$ Dolayısı ile, iM tekniğinde ek büyüme faktörü kullanımının etkilerinin beklenmedik olduğu ve ek çalışmalara ihtiyaç duyulduğu aşikardır.

\section{Gelecek}

Mevcut kanıtlara rağmen, klinik gidişi iyileştirmek amacıyla iM tekniğinin kullanımı ile ilgili konuları netleştirmek için daha ileri araştırmalara gerek vardır. Önemli bir soru, zarın gerçek biyolojik özellikleri ile ilgilidir. Osteoindüktivitesi ile ilgili olarak, immünokimyasal analiz BMP-2 üretimini teyit etse de, yakın zamanda yapılan bir in vivo çalışmada, kemik dışı deri altı bir bölgeye yerleştirilen indüklenmiş membranın bir kalsiyum fosfat biyomateryalinde osteoindüktif özelliklere sahip olmadığı gösterildi. ${ }^{[25]}$ Bu nedenle, membranın salgılayabileceği diğer osteoindüktif faktörleri aydınlatmak ve in vivo osteoindüktivitesini değerlendirmek için ileri araştırmalara ihtiyaç vardır.

íkinci bir husus, biyolojik açıdan aktif bir zar oluşturmaya çalışmak için en uygun tipte ara maddenin seçilmesidir. Şu anda PMMA çimentosu kullanılmaktadır; ancak, potansiyel olarak başka bir spacer kullanılması için ileri araştırmalara ihtiyaç vardır.

Üçüncü olarak, defektin doldurulması için en uygun malzeme seçimi daha iyi mekanik ve biyolojik özellikler açısından araştırılmalıdır. Bunun için, doku mühendisliği ile elde edilen greftlerin kullanımı umut verici bir stratejidir. Bunun klinik önemi büyük olabilir, çünkü enfekte olmamış olgularda veya akut travmatik kemik kaybında, geleneksel iki aşamalı prosedür tek bir prosedüre indirgenebilir.

\section{KAYNAKLAR}

1. Hertel L, Gerber A, Schlegel U, Cordey J, Rüegsegger P, Rahn BA. Cancellous bone graft for skeletal reconstruction. Muscular versus periosteal bed preliminary report. Injury 1994;25 Suppl 1:A59-70.

2. Weiland AJ, Phillips TW, Randolph MA. Bone grafts: a radiologic, histologic, and biomechanical model comparing auto grafts, allografts, and free vascularized bone grafts. Plast Reconstr Surg 1984;74(3):368-79.

3. Pelissier P, Masquelet AC, Bareille R, Pelissier SM, Amedee $J$. Induced membranes secrete growth factors including vascular and osteoinductive factors and could stimulate bone regeneration. J Orthop Res 2004;22(1):73-9. Crossref
4. Masquelet AC, Begue T. The concept of induced membrane for reconstruction of long bone defects. Orthop Clin North Am 2010;41(1):27-37. Crossref

5. Masquelet AC, Fitoussi F, Begue T, Muller GP. Reconstruction of the long bones by the induced membrane and spongy autograft. Ann Chir Plast Esthet 2000;45(3):346-53.

6. Masquelet AC. Induced Membrane Technique: Pearls and Pitfalls. J Orthop Trauma 2017;31 Suppl 5:S36-8. Crossref

7. Morris R, Hossain M, Evans A, Pallister I. Induced membrane technique for treating tibial defects gives mixed results. Bone Joint J 2017;99-B(5):680-5. Crossref

8. Azi ML, Teixeira A, Cotias RB, Joeris A, Kfuri M Jr. Membrane induced osteogenesis in the management of post-traumatic bone defects. J Orthop Trauma 2016;30(10):545-50. Crossref

9. Luo TD, Nunez FA Jr, Lomer AA, Nunez FA Sr. Management of recalcitrant osteomyelitis and segmental bone loss of the forearm with the Masquelet technique. J Hand Surg Eur Vol 2017;42(6):640-2. Crossref

10. El-Alfy BS, Ali AM. Management of segmental skeletal defects by the induced membrane technique. Indian J Orthop 2015;49(6):643-8. Crossref

11. Tydings JD, Martino LJ, Kircher M, Alfred R, Lozman J. The osteoinductive potential of intra medullary canal bone reamings. Curr Surg 1986;43(2):121-4.

12. Frolcke JP, Nulend JK, Semeins CM, et al. Viable osteoblastic potential of cortical reamings from intramedullary nailing. J Orthop Res 2004;22(6):1271-5. Crossref

13. Morelli I, Drago L, George DA, Gallazzi E, Scarponi S, Romanò $\mathrm{CL}$. Masquelet technique: myth or reality? A systematic review and meta-analysis. Injury 2016;47 Suppl 6:S68-76. Crossref

14. Wang X, Luo F, Huang K, Xie Z. Induced membrane technique for the treatment of bone defects due to post-traumatic osteomyelitis. Bone Joint Res 2016;5(3):101-5. Crossref

15. Karger C, Kishi T, Schneider L, Fitoussi F, Masquelet AC; French Society of Orthopaedic Surgery and Traumatology (SoFCOT). Treatment of posttraumatic bone defects by the induced membrane technique. Orthop Traumatol Surg Res 2012;98(1):97-102. Crossref

16. Lowe JA, Della Rocca GJ, Murtha Y, Liporace FA, Stover MD, Nork SE, Crist BD. Complications associated with negative pressure reaming for harvesting autologous bone graft: a case series. J Orthop Trauma 2010;24(1):46-52. Crossref

17. Cook SD, Wolfe MW, Salked SL, Rueger DC. Effect of recombinant human osteogenic protein-1 on healing of segmental defects in non-human primates. J Bone Joint Surg Am 1995;77(5):734-50.

18. Johnson EE, Urist MR, Finerman GA. Repair of segmental defects of the tibia with cancellous bone grafts augmented with human bone morphogenetic protein. A preliminary report. Clin Orthop Relat Res 1988;(236):249-57.

19. Johnson EE, Urist AR, Finerman GA. Resistant non unions and partial or complete segmental defects of long bones. Treatment with implants of a composite of human bone morphogenetic protein (BMP) and autolyzed, antigenextract, allogenetic (AAA) bone. Clin Orthop Relat Res 1992;(277):229-37.

20. Cook SD, Barrack RL, Shimmin A, Morgan D, Carvajal JP. The use of osteogenetic protein-1 in reconstructive surgery of the hip. J Arthroplasty 2001;16(8 Suppl 1):88-94.

21. Cook SD, Barrack RL, Santman M, Patron LP, Salkeld SL, Whitecloud TS 3rd. The Otto Aufranc Award. Strut allograft healing to the femur with recombinant human osteogenic protein-1. Clin Orthop Relat Res 2000;(381):47-57. 
22. Friedlander GE, Perry CR, Cole JD, Cook SD, Cierny G, Muschler GF, Zych GA, Calhoun JH, LaForte AJ, Yin S. Osteogenic protein-1 (bone morphogenetic protein-7) in the treatment of tibial non unions. J Bone Joint Surg Am 2001;83A Suppl 1(Pt 2):S151-8.

23. Salkeld SL, Patron LP, Barrack RL, Cook SD. The effect of osteogenic protein-1 on the healing of segmental bone defects treated with autograft or allograft bone. J Bone Joint Surg Am 2001;83-A(6):803-16.

24. Knutsen R, Wergedal JE, Sampath TK, Baylink DJ, Mohan $\mathrm{S}$. Osteogenic protein-1 stimulates proliferation and differentiation of human bone cells in vitro. Biochem Biophys Res Commun 1993;194(3):1352-8. Crossref
25. Catros S, Zwetyenga N, Bareille R, Brouillaud B, Renard M, Amédée J, Fricain JC. Subcutaneous-induced membranes have no osteoinductive effect on macroporous HA-TCP in vivo. J Orthop Res 2009;27(2):155-61. Crossref

26. Giannoudis PV, Faour O, Goff T, Kanakaris N, Dimitriou R. Masquelet technique for the treatment of bone defects: tips-tricks and future directions. Injury 2011;42(6):591-8. Crossref 